3. Martin Volk, Rico Sennrich, Christian Hardmeier, and Frida Tidstrum. (2010). Proceedings of EM+/CNGL, pages 53-62, Denver, USA.

4. Mirko Plitt and François Masselot. (2010). Prague Bulletin of Mathematical Linguistics, 93:7-16.

5. Sheila C.M. de Sousa, Wilker Aziz, and Lucia Specia. (2011). Proceedings of RANLP, pages 97-103, Hissar, Bulgaria.

DOI https://doi.org/10.30525/978-9934-26-039-1-72

\title{
ВАРІАТИВНІСТЬ ПЕРЕКЛАДУ МЕДИЧНИХ ТЕРМІНІВ У ПОВICТІ Д. К. ДЖЕРОМА «THREЕ MEN IN A BOAT (TO SAY NOTHING OF THE DOG)»
}

\author{
Гриценко С. М. \\ магістрант кафедри англійської та німецької філологї \\ Полтавського начіонального педагогічного університету \\ імені В. Г. Короленка \\ м. Полтава, Украӥна
}

Використання термінів в художній літературі пов'язане з конкретною метою вислову, при цьому терміни виконують неоднакові стилістичні функції у різних за тематикою та жанровістю творах, сприяючи реалістичності зображуваних подій, характеристиці персонажів та ін. [1, c. 374]. Медичні терміни в тексті художнього твору можуть ускладнити завдання перекладача 3 пошуку терміна-еквівалента у мові перекладу, оскільки необхідно зробити його зрозумілим для читача та одночасно зберегти та відтворити задум автора, за виразом А. В. Федорова «висловити вірно і повно засобами однієї мови те, що вже виражено раніше засобами іншої мови» [2, с. 10].

Було проаналізовано переклади повісті Джерома К. Джерома «Three Men in a Boat (To Say Nothing of the Dog)», виконані В. Прокопчуком (1956), Ю. Лісняком (1974), Ю. Якушиком (2011), О. Негребецьким (2014) українською мовою та переклади М. А. Енгельгардта (1901), Є. Кудашевої (1912), М. Сал'є (1957), Е. Лінецької та М. Донськоого (1958), Г. Сєвєра (1996) російською мовою.

На початку твору автор іронізує над головним героєм Джеєм, який знаходить у себе всі хвороби, які містяться у медичному довіднику: " I sat for awhile, frozen with horror; and then, in the listlessness of despair, I again turned over the pages. I came to typhoid fever - read the symptoms 62 
discovered that I had typhoid fever, must have had it for months without knowing it - wondered what else I had got; turned up St. Vitus's Dance found, as I expected, that I had that too, - began to get interested in my case, and determined to sift it to the bottom, and so started alphabetically - read up ague, and learnt that I was sickening for it, and that the acute stage would commence in about another fortnight. Bright's disease, I was relieved to find, I had only in a modified form, and, so far as that was concerned, I might live for years. Cholera I had, with severe complications; and diphtheria I seemed to have been born with. I plodded conscientiously through the twenty-six letters, and the only malady I could conclude I had not got was housemaid's knee.

I felt rather hurt about this at first; it seemed somehow to be a sort of slight. Why hadn't I got housemaid's knee? Why this invidious reservation? After a while, however, less grasping feelings prevailed. I reflected that I had every other known malady in the pharmacology, and I grew less selfish, and determined to do without housemaid's knee. Gout, in its most malignant stage, it would appear, had seized me without my being aware of it; and zymosis I had evidently been suffering with from boyhood. There were no more diseases after zymosis, so I concluded there was nothing else the matter with me» [3, c. 12].

Загалом автор використав у уривку 14 медичних термінів, 9 з яких $є$ назвами хвороб. Особливо цікавим та дискусійним $є$ переклад назви тієї єдиної хвороби, яку Джей в себе не знайшов - housemaid's knee, буквально: коліно покоївки. Назва хвороби походить 3 часів, коли при митті підлоги покоївкам доводилося тривало стояти на колінах. У коліні $\epsilon$ кілька слизових сумок, які можуть бути пошкоджені в результаті такого навантаження. Ця мікротравматизація призводить до бурситу запалення сухожилкових сумок колінного суглобу. Інші «народні» назви захворювання англійською beat knee (побите коліно), carpet layer's knee (коліно устилача коврів), coal miner's knеe (коліно шахтаря), rug cutter's kneе (коліно закрійника) свідчать, що ця хвороба була притаманна людям, що займалися фізичною працею та відносилися до нижчих верств суспільства, але аж ніяк не джентльменам. Тож комізм ситуації полягає в тому, що саме цієї єдиної хвороби герой, джентльмен 3 вищого суспільства, що має «a general disinclination to work of any kind» 'загальну відразу до будь-якої праці' - у себе не знайшов [4, с. 90].

В. Прокопчук переклав хворобу просто - «єдиним захворюванням якого в мене не було, як я міг зробити висновок, був гоніт» (запалення колінного суглобу) [5, с. 6]. Переклад Ю. Якушика відображає лише прояв захворювання: «єдине, чого в мене не було, то ие води в коліні» 
[6, с. 8]. М. Сал'є також переклав назву хвороби як «запалення колінної чашечки» $[7$, с. 6]. Г. Сєвєр використав власний термін - «стерті коліна» [8, с. 9], С. Кудашева - «хронічна виразка гомілки» [9, с. 6]. В усіх випадках такого буквального перекладу втрачаються потрібні асоціації. Ю. Лісняк для збереження задуму автора використовує назву хворобу, що також не можлива для героя: «не знайшов у себе тільки однієї-раку сажотрусів» $[10$, с. 9].

Деякі перекладачі для відтворення гумору обрали інший шлях перекладу. В перекладі М. А. Енгельгардта - «единственная болъзнь, которой у меня ие оказалось, была блюдная немочь» [11, с. 5]. Бліда неміч - стан недокрів'я, що з'являється виключно у дівчат в період статевого розвитку. О. Негребецький також повністю змінив назву хвороби: «єдиною хворобою, якої я у себе не знайшов, була мастопатія» [12, с. 5]. Аналогічно в перекладі М. Донського та Е. Лінецької: «единственная болезнь, которой я у себя не обнаружил, была родильная гарячка» $[13$, с. 5], що зовсім змінює суть гумору - герой не знайшов у себе цієї хвороби через свою стать, а не через те, що джентльмени за часів вікторіанської Англії не займалися тяжкою фізичною працею.

Іронізуючи над невіглаством героя, автор пише, що той знайшов у себе всі хвороби, що відомі фармакології, хоча фармакологія це наука не про хвороби, а про лікарські засоби. В усіх варіантах перекладачі, окрім М. А. Енгельгардта, використали вислів «ще відомі медищині», втративши гумористичну складову.

Сам перелік хвороб також $\epsilon$ не випадковим. Автор говорить, що Джей переглянув їх усі за алфавітом: «ague, Bright's disease, cholera, diphtheria, gout, housemaid's knee, zymosis» [3, c. 12], про що згадують і всі перекладачі твору.

За словником назви хвороби переклали В. Прокопчук: «малярія», «Брайтова хвороба», «холера», «дифтерит», «гоніт», «подагра», «інфекиійні захворювання» [5, с. 6] та О. Якушик: «малярія», «хвороба Брайта», «холера», «дифтерія», «вода в коліні», «подагра», «інфекиійні хвороби» [6, с. 8]. В перекладі ж Ю. Лісняка назви наступні: «ангіна», «брайтова хвороба, тобто запалення нирок», «віспа», «дифтерит», «рак сажотрусів», «сухоти», «ящур» [10, с. 9]. О. Негребецьким назви хвороб перекладено так: «анурія», «хвороба Брайта», «віспа», «дифтерія», «мастопатія», «подагра», «ямур» [12, с. 5].

В перекладах російською перекладачі використали наступні назви хвороб. М. Сал'є: «атаксия», «Брайтова болезнь», «дифтерит», «холера», «воспаление коленной чамечки», «подагра», «общее предрасположение к инфекиии» [7, с. 6]. 
Г. Сєвєр: «болотная лихорадка», «Брайтова болезнь», «холера», «дифтерия», «стертые колени», «подагра», «ятрогенный зимос» $[8$, с. 9].

Є. Кудашева: «премежающаяся лихорадка», «Брайтова болезнь», «холера», «дифтерит», «хроническая язва голени», «подагра» [9, с. 6].

Е. Лінецька та М. Донський: «анемия», «Брайтова болезнь», «воспаление легких», «грудная жаба», «родильная горячка», «тифозная горячка», «ямур» [13, с. 5].

Отож, тільки у перекладах Ю. Лісняка та О. Негребецького українською та у перекладі Е. Лінецької та М. Донського російською мовою хвороби перелічені у алфавітному порядку, що сприяє створенню органічного тексту перекладу та відтворенню необхідних асоціацій у читача.

Таким чином, переклад медичних термінів у художніх текстах, особливо назв хвороби, викликає певні труднощі при перекладі 3 англійської мови. Це вимагає від перекладача знання не лише лексикограматичних особливостей мови оригіналу, але й історичних та етнокультурних особливостей того часу, коли певні терміни з'явились.

\section{Література:}

1. Чрділелі Т., Мельникова А. Особливості функціонування термінів у контексті художнього твору. Теоретична і дидактична філологія. 2013. Вип. 16. C. 371-379. URL: http://nbuv.gov.ua/j-pdf/Tidf_2013_16_43. (дата звернення: 14. 02.2021).

2. Федоров А.В. Основы общей теории перевода (Лингвистические проблемы). 4-е изд., перераб.и доп. М.: Высш. школа, 1983. 303 с.

3. Jerome K. Jerome Three men in a boat. Three men on a bummel. Oxford: Oxford university press, 1998. 368 p.

4. Підгрушна О.Г. Відтворення англійського гумору в українському художньому перекладі: дис. ... канд. філол. наук : 10.02.16 / Київський нац. ун-т імені Тараса Шевченка. К., 2015. 227 с.

5. Джером К. Джером Троє в одному човні (нічого не кажучи про собаку); пер. з англ. Володимир Прокопчук. К.: Державне видавництво художньої літератури, 1956. $176 \mathrm{c}$.

6. Джером К. Джером Троє в одному човні (якщо не рахувати собаки) / пер. з англ. Олег Якушик. К.: Країна Мрій, 2011. 250 с.

7. Джером Клапка Джером Трое в лодке, не считая собаки / пер. М. Салье. М.: АСТ, 2009. 300 с.

8. Джером Клапка Джером, Трое в лодке (не считая собаки) / пер. Г. Севера. М.: Нигма, 1996. 320 с. 
9. Джером К. Джером Трое в лодке, не считая собаки / пер. с англ. кн. Е. С. Кудашевой. URL: https://litportal.ru/avtory/dzherom-kdzherom/kniga-troe-v-lodke-ne-schitaya-sobaki-219321.html (дата звернення: 12. 02.2021).

10. Джером К. Джером Троє в одному човні (як не рахувати собаки). Оповідання / пер. з англ. Юрій Лісняк.К. : Дніпро, 1974. 311 с.

11. Джеромъ К. Джеромъ. Трое въ одной лодкЂ (кромЂ собаки). Переводъ съ англійского М. А. Энгельгардта. Москва. Польза. URL: https://imwerden.de/pdf/jerome_k_jerome_troe_v_lodke_krome_ sobaki_1911_text.pdf (дата звернення: 10. 02.2021).

12. Джером К. Джером Троє у човні (не кажучи про пса) / пер. 3 англ. Олекса Негребецький. К. : Знання, 2014. 236 с.

13. Джером К. Джером. Трое в лодке, не считая собаки / пер. с англ. М. Донского, Э. Линецкой. СПб. : Кристалл, 2002. 255 с.

DOI https://doi.org/10.30525/978-9934-26-039-1-73

\title{
РЕАЛІЇ В СИСТЕМІ БЕЗЕКВІВАЛЕНТНОЇ ЛЕКСИКИ
}

\author{
Кабаченко І. Л. \\ доиент кафедри перекладу \\ Національного технічного університету «Дніпровська політехніка» \\ м. Дніпро, Украӥна
}

Стрімкий темп змін словникового складу мов був викликаний розвитком виробництва, культури і науки тієї чи іншої країни. Очевидним фактом є те, що абсолютно в будь-якій мові є слова, які не мають відповідності в іншій мові.

У тому випадку, якщо у лексичної одиниці немає відповідного їй лексичного еквівалента в мові - перекладач стикається 3 явищем безеквівалентності. Воно відображає специфічні явища культурної своєрідності того чи іншого народу.

Багато дослідників займалися проблемою безеквівалентної лексики, наприклад, Р. П. Зорівчак, С. Влахов, Г. Д. Томахін, С. Флорин, А. Д. Швейцер [1-4] та інші автори.

У межах безеквівалентної лексики реалії виділяють в окрему перекладознавчу категорію, i належать до найменш вивчених лінгвістичних одиниць. Визначення поняття «реалія», поряд 3 не дуже 